\title{
Therapeutic Bronchoscopy In Patients with Symptomatic Airway Lesions Argon Plasma Coagulation / Electrocautery
}

\author{
Aydan MERTOGLU, Ahmet E. ERBAYCU, Salih Z. GUCLU, Ayse OZSOZ, Rifat OZACAR \\ Izmir Training and Research Hospital for Thoracic Medicine and Surgery, \\ Department of Pulmonology, Izmir, TURKEY
}

\begin{abstract}
Endobronchial treatments are widely used for treating airway obstruction with the goal of relieving large airway obstructions caused by malignant or benign lesions. However, they may be curative in patients with benign conditions. We aimed to evaluate the usefulness of endobronchial argon plasma coagulation (APC) and electrocautery (EC) for treating patients with airway obstruction. Methods: We conducted a retrospective study in the bronchoscopy unit of a training and research hospital. Endobronchial treatment was carried out in 56 evaluable patients between 2007 and 2012. We used a rigid bronchoscope in 18 patients and flexible bronchoscope in 38 patients. General anaesthesia was administered to 32\% (18 patients) patients. Bronchogenic carcinoma was seen in 43 patients, metastatic bronchial tumours in 1, and benign airway disease in 12. Obstruction sites were the trachea in 15 patients, main stem bronchi in 28 and lobar bronchi in 5. Eight patients had obstruction at multiple sites. Mean degree of obstruction was $84 \%$. Immediately after the treatment, the mean degree of obstruction was 44\%. Mean overall decrease in degree of obstruction was $39 \%$. Post-tretament improvement of dyspnoea was excellent in 31 cases (55\%) and moderate in 23 cases (41\%); dyspnoea improvement was absent in 2 cases. Three complications ( 2 cases of respiratory insufficiency, 1 of mediastinal emphysema) were directly related to the endobronchial treatment. Conclusion: APC and EC are effective, rapid and repeatable techniques for treating endoluminal airway lesions and can effectively decrease dyspnoea.
\end{abstract}

Keywords: Airway obstruction, Argon plasma coagulation, Electrocoagulation, Bronchoscopy

ÖZET

Semptomatik Hava Yolu Lezyonu Olan Hastalarda Bronkoskopik Tedavi Argon Plazma Koagülasyonu /Elektrokoter Endobronşiyal tedaviler, malign ya da benign lezyonların neden olduğu büyük hava yolu obstrüksiyonlarında palyatif amaçla yaygın olarak kullanımaktadır. Bu tedaviler benign durumlarda küratif olabilmektedir. Bu çalışmada hava yolu obstrüksiyonlarının tedavisinde endobronşiyal argon plazma koagülasyonu (APC) ve elektrokoterin (EC) yararılığını değerlendirmeyi amaçladık. Çalışma retrospektif olarak bir eğitim araștırma hastanesi bronkoskopi ünitesinde yürütüldü. 2007-2012 yılları arasında 56 hastaya endobronşiyal tedavi uygulandı. On sekiz hastada rijid, 38 hastada fiberoptik bronkoskop ile işlem yapıldı. Hastaların \%32 sinde (18 hastada) genel anestezi uygulandı. Kırküç olguda bronş karsinomu, 1 olguda metastatik tümor, 12 hastada benign hava yolu darlığı mevcuttu. Onbeş hastada trakeada, 28 hastada ana bronşta, 5 hastada lober bronş düzeyinde, 8 hastada birden fazla yerde obstrüksiyon mevcuttu. Obstrüksiyon derecesi ortalaması \%84 idi. Tedaviden hemen sonra saptanan obstrüksiyon derecesi ortalaması \%44 idi. Obstrüksiyon derecesindeki azalmanın ortalaması \%39 olarak bulundu. Tedavi sonrası dispnede düzelme 31 olguda(\%55) "mükemmel”, 23 olguda(41) "orta düzeyde" saptandı, 2 olguda dispnede düzelme görülmedi. Endobronşiyal tedavi ile ilişkili komplikasyon 3 olguda görüldü.(2 olguda solunum yetmezliği, 1 olguda mediasten anfizemi). APC ve EC endobronşiyal lezyonların tedavisinde kullanılan, dispneyi etkin bir şekilde azaltabilen, hızlı etkili, tekrarlanabilir tetkiklerdir .

Anahtar Kelimeler: Hava yolu obstrüksiyonu, Argon plazma koagülasyonu, Elektrokoter, Bronkoskopi 


\section{INTRODUCTION}

Endobronchial ablative therapies include laser, electrocautery, argon plasma coagulation, cryotherapy, brachytherapy and photodynamic therapy. Endobronchial ablative techniques can result in significant improvements in symptoms, quality of life and life expectancy in patients with symptomatic airway lesions. Technical and instrumental developments have provided the bronchoscopist with several alternatives for bronchoscopic therapeutic interventions. ${ }^{1,2}$

The majority of patients with malignant tracheobronchial neoplasms have a dismal prognosis and eventually require palliative treatment. Tracheal and main bronchial obstructions, with consequent respiratory distress, are observed in $30 \%$ lung cancer cases. ${ }^{3}$ Systemic treatment is often supported with local palliative interventions for complications, particularly respiratory failure and bronchial infections. Endobronchial treatment techniques play an important role in all of these situations because conventional treatments for airway patency are usually unsatisfactory in such patients. ${ }^{4}$ Significant airway obstruction with imminent suffocation requires immediate action to promptly regain airway patency. The majority of patients referred to interventional pulmonologists suffer from end-stage tumour recurrence, after failing previous chemoradiotherapy regimens. ${ }^{5}$

Endoscopic treatment has been increasingly used for treating benign endobronchial lesions. Endobronchial metastases of extrathoracic tumours, benign tumours and secondary airway stenosis (iatrogenic or postinfectious cicatricial stenoses) can also cause tracheal and main bronchial obstructions, requiring immediate treatment. Although endoscopic procedures are generally considered as palliative, they can be curative for benign lesions. ${ }^{6-16}$

APC and EC have been widely used and accepted for the management of benign and malignant airway lesions. ${ }^{6-30} \mathrm{EC}$ is defined as the application of a highfrequency electrical current via a probe to coagulate or vaporise tissue. APC is a non-contact mode of monopolar electrical coagulation, in which argon gas is used as the conductive medium. Both EC and APC make use of electrically- generated heat to destroy tissue. Depending on the energy used, either coagulation or vaporisation can be induced. ${ }^{5,17,20}$
APC produces a more homogeneous, superficial thermal effect owing to its non-contact nature and lower energy density. Thus, it is preferred for larger lesions. APC is also indicated for coagulation of haemorrhages from an endoscopically visible source. ${ }^{5,17} \mathrm{En}$ dobronchial $\mathrm{EC}$ is an excellent alternative to laser for treating airway lesions. Indications for EC are essentially similar to those for laser surgery. ${ }^{18-22} \mathrm{EC}$ and APC can produce immediate effects ${ }^{5}$ and are straightforward and simpler than laser. These techniques provide lower-risk alternatives than other interventional endobronchial techniques. ${ }^{17,19,21-24}$ This study aimed to assess the effectiveness of endobronchial treatment carried out with APC and EC in symptomatic malignant or benign airway lesions.

\section{PATIENTS and METHODS}

Fifty-six patients who underwent endobronchial treatment with APC and EC because of symptomatic benign or malignant airway lesions between 2007 and 2012 were included in this study. The study has a retrospective design, and the approval of the Ethical Committee is not required for the conduct of studies with retrospective design in our hospital.

Patients with malignant conditions were regarded as inoperable because of private or medical reasons, with conditions not benefitting from chemoradiotherapy. Some patients did not accept chemoradiotherapy or their main airway obstruction required immediate treatment before chemoradiotherapy. Patients with airway-obstructing neoplasms were included in this study if they met all of the following criteria: (1) symptoms were related primarily to airway obstruction and not to systemic disease, (2) the tumour was located within the airway lumen, (3) tumour length was $\leq 3.5 \mathrm{~cm}$ and (4) there was functional lung distal to the obstruction. ${ }^{17}$ Endobronchial treatment was carried out in cases with bronchoscopic airway obstruction of benign causes, when surgical treatment was clinically or technically impossible or when the patient did not consent to surgical treatment.

Endobronchial procedures were performed via flexible or rigid bronchoscopy. Pulse oximetry saturation, blood pressure and pulse were monitored during bronchoscopy. Rigid bronchoscopy was performed in patients with large bulky lesions in the central airway when the patient qualified for general anaesthe- 
sia. Flexible bronchoscope was preferred in cases of small superficial lesions in the lobar bronchi. Fibreoptic bronchoscopy was used along the inner part of rigid bronchoscope in some cases.

Rigid bronchoscopy was always performed under general anaesthesia; the flexible fibreoptic bronchoscope alone was employed always under local anaesthesia. Local anaesthesia and conscious sedation with intravenous midazolam was administered before and during the procedures. All procedures were performed transorally in the bronchoscopy suite or operation room. For general anaesthesia, rocuronium (induction dose of $0.6 \mathrm{mg} / \mathrm{kg}$, maintenance dose of $0.15 \mathrm{mg} / \mathrm{kg}$ ), propofol (induction dose $1.5-2.5 \mathrm{mg}$ / $\mathrm{kg}$, maintenance dose $4-12 \mathrm{mg} / \mathrm{kg} / \mathrm{h}$ infusion) and remifentanil [bolus infusion $1 \mu \mathrm{g} / \mathrm{kg}$ (applied in at least $30 \mathrm{~min}$ ), continuous infusion dose 0.05-2.0 $\mu \mathrm{g}$ / $\mathrm{kg} / \mathrm{min}$ ] were used.

Endobronchial treatment was carried out with an electrosurgery unit (ESU)/APC unit (ERBE ICC 200 EA; and APC 300 combination, Tübingen, Germany) via flexible (model EB 1970, 2.8 model) or rigid broncoscope (EFER- DUMON BRONCHOSCOPE BT series; Marseille, France). The ESU (EC) has a constant-voltage-cutting feature with 4 adjustable voltage levels. This allows the vaporisation of tissue because of a dense concentration of electrical energy with minimal and controllable lateral thermal spread. Conversely, the SOFT and FORCED coagulation modes enable the use of slow dispersive and quick effective coagulations, respectively. For polypectomy procedures, ESU has special Endo- Cut function, which allows pre-coagulation, cutting and superficial coagulation intermittently and automatically. During a polypectomy procedure, the unit adjusts the output power automatically according to the selected hemostasis level.

The probes are inserted through the working channel of the bronchoscope. Once the target tissue is endoscopically visualised, it can be coagulated or vaporised and the devitalised tissue can be mechanically removed by forceps. 48-72 hours after the first endoscopic treatment, control bronchoscopy was performed on all suitable patients. The patients who had incomplete lesion debulking after 1 treatment underwent a second bronchoscopic treatment after 48-72 h.
In the case of recurrent lesions, additional endobronchial treatments were carried out on patients who met the inclusion criteria. Patients who had undergone treatments for benign lesions were followed up with surveillance bronchoscopy 2-3 months after therapy and as indicated clinically.

Patient demographic characteristics, dyspnoea severity, airway lesion locations, airway obstruction types, obstruction degrees, therapeutic response and complications were recorded. The percentage of airway obstruction was estimated by visual comparison between the stenotic area and the healthy proximal airway. ${ }^{17}$

Dyspnoea severity before and after treatment (right after treatment ) was also assessed by the Borg scale (range, 0-10). A higher score on the Borg scale indicates a more severe respiratory disorder. In the study, Borg 0-2 was identified as mild dyspnoea, 3-4 as moderate dyspnoea, 5-6 as severe dyspnoea, 7-10 as critically severe dyspnoea. ${ }^{31}$ Post-tretament dyspnoea improvement was classified as excellent if, on the basis of patients' estimations, the dyspnoea resolved or was at least reversed to the level before the onset of the airway obstruction. Improvement was classified as moderate if the dyspnoea improved without complete resolution and the level was worse than that before the onset of airway obstruction. ${ }^{17}$

\section{RESULTS}

Endobronchial treatment was carried out in 56 cases (75 procedures) in which an airway lesion was detected between 2007 and 2012. All patients were hospitalised for their primary clinical conditions and bronchoscopic intervention.

We used rigid bronchoscopy in 18 patients and fibreoptic bronchoscopy in 38; general anaesthesia was administered to $32 \%$ patients. Forty-three patients had malignant diseases, 1 had a metastatic tumour affecting the bronchi and 12 had benign airway disease. Demographic characteristics and diagnoses of the patients are shown in Table 1.

Symptomatic endoluminal airway obstruction was the indication for treatment in all patients. Obstruction sites were the trachea in 15 patients, main stem bronchi in 28 and lobar bronchi in 5. Eight patients 


\begin{tabular}{|lc|}
\hline $\begin{array}{l}\text { Table 1. Demographic characteristics and diagnoses of } \\
\text { the patients }\end{array}$ & Values (n) \\
\hline $\begin{array}{l}\text { Demographic } \\
\text { Characteristics/ } \\
\text { Diagnosis }\end{array}$ & \\
\hline Sex & 50 \\
Male & 6 \\
Female & $61.60 \pm 11.38$ (range, 21-80) \\
Median age, years & 43 \\
Diagnosis Malignant Diseases & 36 \\
$\quad$ Non-small cell lung cancer & 3 \\
Small cell lung cancer & 3 \\
Typical carcinoid & 1 \\
Adenoid cystic carcinoma & 2 \\
Metastatic disease & 1 \\
Benign Diseases & 12 \\
Cicatricial stenosis & 1 \\
Hamartoma & 2 \\
Polyp & 1 \\
Post-intubation stenosis & 8 \\
& \\
\end{tabular}

had multiple obstructions sites. Following intervention, 54 of 56 patients reported dyspnoea improvement.

Subjective dyspnoea intensity scores reported by the patients before and after interventional procedure using the Borg's Dyspnoea Scale are shown Table 2.

Dyspnoea severity and the airway lesion locations are shown in Table 3. Lesion locations and therapeutic interventions used are shown in Table 4. Patients with endoluminal masses had a mean (standard deviation) pre-treatment reduction of the healthy airway of

\begin{tabular}{|lll|}
\hline $\begin{array}{l}\text { Table 2. Subjective dyspnoea intensity scores reported by } \\
\text { the patients before and after the interventional procedure } \\
\text { using the Borg's Dyspnoea Scale }\end{array}$ \\
\hline Borg Score & $\begin{array}{l}\text { Before } \\
\text { treatment }\end{array}$ & $\begin{array}{l}\text { After } \\
\text { treatment }\end{array}$ \\
\hline 0, None & 0 & 5 \\
0.5-2, Slight & 2 & 26 \\
3-4 Moderate & 8 & 23 \\
5-6 Severe & 44 & 2 \\
7-10, Very Severe & 2 & 0 \\
\hline
\end{tabular}

$83.57 \% \pm 18$. Immediate post-treatment average obstruction size was $44.19 \% \pm 28.28$ and mean overall decrease in degree of obstruction was $39.38 \%$. Dyspnoea improvement immediately after treatment was excellent in 31 cases (55\%) and moderate in 23 cases $(41 \%)$. Two patients did not experience dyspnoea improvement. One patient developed respiratory insufficiency, which required mechanical ventilation. The other patient, a woman with adenoid cystic carcinoma, had persistent dyspnoea after the procedure. Thus, she had endobronchial treatment failure, but did not develop complications. The type of airway obstruction and therapeutic response are shown in Table 5.

Approximately 74 days after the initial treatment, the procedure was repeated a second time in 4 patients having malignant obstruction (non-small cell lung cancer). In 3 patients (adenoid cystic carcinoma, carcinoid tumour and non- small cell lung cancer), the procedure was repeated 3 times every 62 days as a consequence of recurring obstruction.

\begin{tabular}{|c|c|c|c|c|c|}
\hline \multirow[t]{2}{*}{ Location of airway lesions } & \multirow[t]{2}{*}{ n (\%) } & \multicolumn{4}{|c|}{ Dyspnoea severity } \\
\hline & & Very sever & Severe & Moderate & Low \\
\hline Trachea & $15(26.7)$ & & 14 & & 1 \\
\hline Main bronchi & $28(50)$ & 2 & 26 & & \\
\hline Lobar bronchi & $5(8.9)$ & & & 5 & \\
\hline Trachea + main bronchi & $5(8.9)$ & & 4 & & 1 \\
\hline Main bronchi + lobar bronchi & $2(3.57)$ & & & 2 & \\
\hline Trachea + lobar bronchi & $1(1.78)$ & & & 1 & \\
\hline Overall n (\%) & 56 & $2(1.78)$ & $44(78.5)$ & $8(14.3)$ & $2(1.78)$ \\
\hline
\end{tabular}




\begin{tabular}{|c|c|c|c|}
\hline Location of airway lesions & & $\begin{array}{l}\text { Therapeutic } \\
\text { intervention }\end{array}$ & $\mathbf{n}$ \\
\hline Trachea & 15 & $\begin{array}{l}\mathrm{AC}^{\star} \\
\mathrm{AC}+\mathrm{EC} \\
\mathrm{EC}^{\star \star}\end{array}$ & $\begin{array}{l}8 \\
6 \\
1\end{array}$ \\
\hline Main bronchi & 28 & $\begin{array}{l}A C \\
A C+E C\end{array}$ & $\begin{array}{l}15 \\
13\end{array}$ \\
\hline Lobar bronchi & 5 & $A C$ & 5 \\
\hline Trachea + main bronchi & 5 & $\begin{array}{l}A C \\
A C+E C\end{array}$ & $\begin{array}{l}3 \\
2\end{array}$ \\
\hline Main bronchi + lobar bronchi & 2 & $A C+E C$ & 2 \\
\hline Trachea + lobar bronchi & 1 & $A C+E C$ & 1 \\
\hline $\begin{array}{l}{ }^{\star} \mathrm{AC}: \text { argon plasma coagulation } \\
{ }^{\star \star} \mathrm{EC} \text { : electrocautery }\end{array}$ & & & \\
\hline
\end{tabular}

In 2 cases of post-intubation tracheal stenosis, the second procedure was needed because of stenosis that developed in 60 and 90 days later in each case. In the remaining benign pathologies, the procedure proved curative and no relapse occurred in the 3-year followup period.

In patients with malignant disease, dyspnoea improvement was maintained for a median follow-up period of 84 days (range, 30-150 days). There were 3 complications ( 2 cases of respiratory insufficiency and 1 of mediastinal emphysema) directly related to endobronchial therapy. One patient developed respiratory insufficiency and mechanical ventilation was required for recovery. The mediastinal emphysema regressed spontaneously in 4 days.

\section{DISCUSSION}

Several techniques are available for the bronchoscopic treatment of tracheobronchial obstructions. APC, EC and Laser can destroy tissue rapidly in a single session. Laser is commonly used in this scenario, but expense limits the availability of laser equipment in many parts of the world. In contrast, APC and EC are alternative modes of thermal tissue destruction at a more accessible cost. ${ }^{20}$

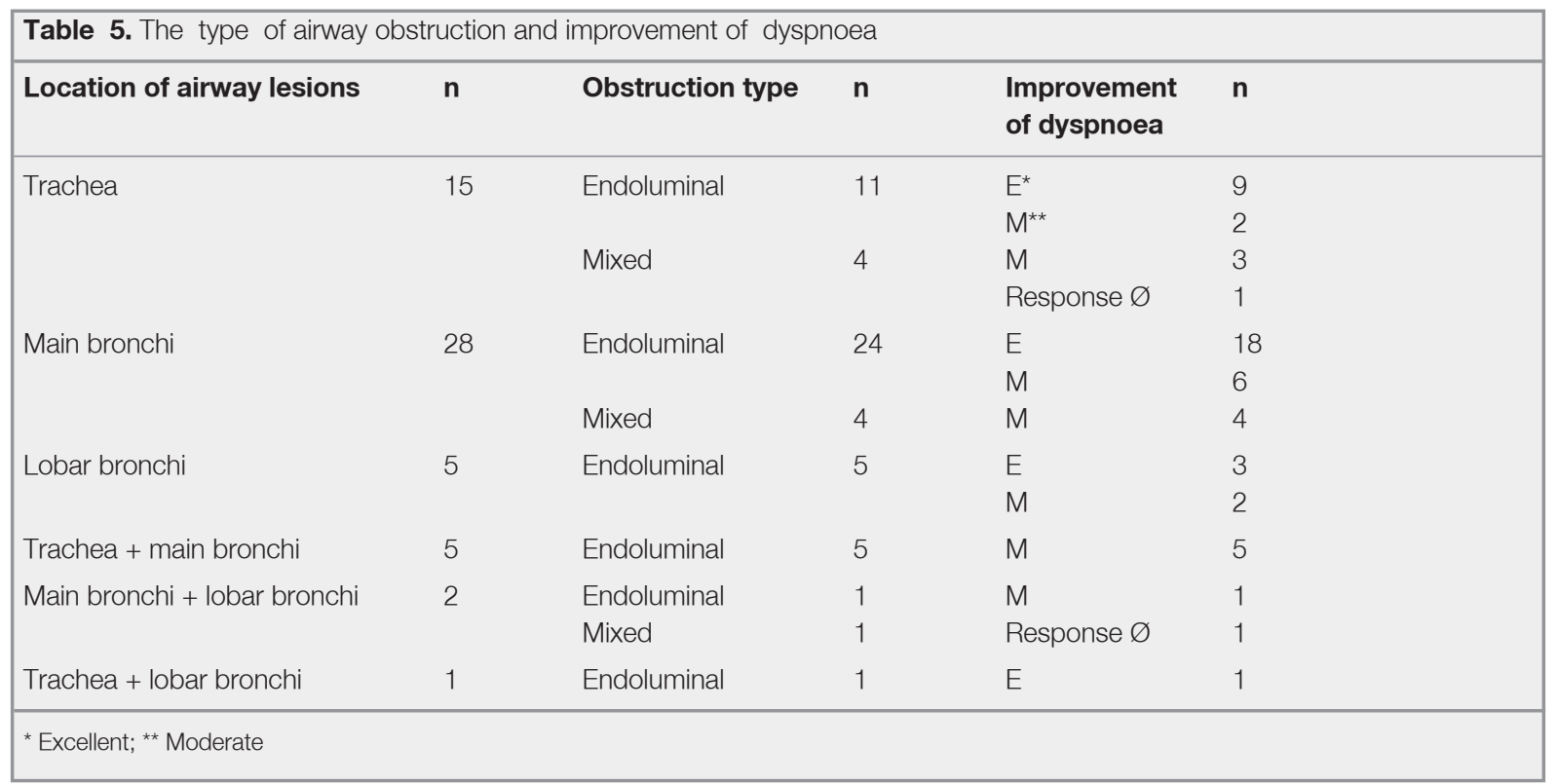


Studje et al reported successful results in their study involving 56 cases with intraluminal tumour in large airways treated with EC in $1997 .{ }^{18}$ Morice et al, in 2001, reported positive results regarding haemopytsis and airway obstruction in their 60-case series, in which APC with fibreoptic bronchoscopy was performed. ${ }^{17}$

Crosta et al., reported a 91\% success rate for treating malignant airway obstruction and haemoptysis with APC. ${ }^{27}$ Coulter et al reported a high success rate of $86 \%$ using EC under local anaesthesia in a select group of patients with small endobronchial benign/ malignant polypoid lesions. ${ }^{21}$ A prospective cohort study of 364 patients who underwent APC reported a success rate of $67 \%$, defined as full or partial airway recanalization. ${ }^{30}$ Therefore, all studies evaluating APC and EC as palliative treatment of airway obstruction indicate their safety and effectiveness.

Although the above studies focused on APC and EC in patients with manifestations of malignant airway disease, these techniques have been used successfully for treating benign disorders, such as granulation tissue formation secondary to stents, airway anastomoses and typical carcinoid and benign endobronchial polyps. Effective treatment were reported in papillomatosis, hamartoma, pleomorphic adenoma, endobronchial metastases. ${ }^{6-16,25,26,28,29}$

Masanori et al reported successful treatment outcomes with APC in 2 cases with post-intubation stenosis in 2006. ${ }^{16}$ In 2012, Faguang et al also reported successful results with APC in 41 patients having endobronchial tuberculosis. ${ }^{13}$

Keller et al. reported successful use of APC for treating airway complications after solid organ transplantation (5 patients). ${ }^{28}$ Sato et al reported successful use of APC and tranilast for treating airway obstruction by granulation tissue after tracheal anastomosis in $2000 .{ }^{25}$ Cappacio et al reported the effectiveness of APC for treating centrally located malignant melanoma metastases, highlighting its palliative application. ${ }^{29}$

Endoscopic treatment of tracheobronchial lesions is mainly aimed at decreasing respiratory distress by providing airway patency, thus improving the patient's quality of life. ${ }^{14}$ Although palliation could also be achieved by mechanical debridement, such as cryotherapy, ${ }^{1,32-33} \mathrm{APC}$ and EC allow quicker and bet- ter results in terms of immediate and medium-term palliation. ${ }^{5,6-17,22,25-29}$

In the present study, the effectiveness and safety of APC and EC for treating endoluminal and mixed central airway lesions of benign and malignant causes were presented.

In interventional pulmonology, various available methods are being applied currently. Techniques involving heat (laser, EC and APC) achieve rapid haemostasis enabling mechanical debulking of obstruction tumours. Both APC and EC are simpler clinical application than Nd-YAG laser. APC allows a rapid coagulation with minimal manipulation and mechanical trauma to the target tissue. Rigid bronchoscopy has advantages in terms of airway control and the ability to easily remove a large volume of tumour and dilate the airway. However, APC and EC have been introduced in to the field of flexible bronchoscopy and these modalities have been used for treating benign and malignant endobronchial lesions. They are safe, simple to use and of a relatively lower cost. Complications such as haemorrhage, airway perforations, airway burns, and respiratory failure can occur but are rare. ${ }^{7,14,15,17,21,22,34-37}$ Reichle et al reported that the APC complication ratio was $3.7 \% .^{30}$ Shaw, et al. and Reddy et al reported a case of cerebral gas embolisation that occurred during bronchoscopic APC. ${ }^{38,39}$

The results of our study confirm the effectiveness of APC and EC reported by previous studies. The results demonstrate that in an appropriate patient population these techniques can provide a significant improvement in dyspnoea.

Proper patient selection for endobronchial therapy is very important. Patients selected should have primarily respiratory rather than systemic symptoms of widespread malignancy. Airway lesions that are most suitable for endobronchial treatment are those measuring $\leq 3.5-4.0 \mathrm{~cm}$ in length. To obtain the best results, these lesions should be predominantly intraluminal and not extend beyond the cartilage of the airway. Ideally, the bronchoscopist should be able to identify the anatomical boundaries of the tumour and visualise that the airway not invaded by tumour is well preserved. ${ }^{17}$

For obstructive tumoral lesions that were $4 \mathrm{~cm}$ long at most and that did not expand out of the airway, we carried out airway lesion demonstrations through to- 
mography reconstructions before bronchoscopy. We did not assess the cartilage involvement through endobronchial ultrasonography.

Our study results indicate that the recovery in dyspnoea lasted for an average of 3 months after endobronchial treatment in malignant cases. For cases in which no recovery in dyspnoea was observed, the reason was thought to be the underlying respiratory diseases, such as fibrosis and chronic obstructive lung disease.

In particular, in malignant lesions, the recanalisation procedure of rigid bronchoscopy using thick probes had a shorter duration. In benign cases, however, the procedure was markedly shorter, not requiring repetition, except for 2 cases with post-intubation stenosis. This process was carried out more easily in patients with benign stenosis. The patients immediately reported a relief in symptoms after the procedure. The lumen was recanalised in a short time by fibreoptic bronchoscopy in a case with stenosis due to granulation tissue.

Although tracheal reconstruction still remains the best treatment for post- intubation tracheal stenosis, endobronchial treatment can be preferred for patients who cannot undergo surgery because of medical or personal reasons. Relapse was seen in our 2 cases of post-intubation stenosis, ${ }^{5,23}$ and the procedure was repeated.

Although the stenotic field length ( 3 and $4 \mathrm{~cm}$ long) was short in these cases, circumferential obstruction was observed. In the literature, endobronchial treatment success is low in cases of circumferential tracheal stenosis. ${ }^{40}$

Treatments with APC and EC in benign lesions can be curative. ${ }^{6-16}$ Therefore, these treatment methods should be considered for select inoperable patients with benign stenosis. We succeeded in curative treatment of cases with stenosis caused by benign diseases (polyp, hamartoma and post-operative cicatricial stenoses). Although we assessed a small number of cases, our study also documented the usefulness of APC and EC therapy for benign tracheobronchial stenosis.

Our study had several limitations. There was a small study population. No additional outcomes were obtained other than the success of radical treatment of
APC and EC in benign cases and the successful palliative treatment in malignant cases. We confirmed the efficiency of APC and EC in decreasing dyspnoea, helping the patients recover from clinical symptoms and improving quality of life. We did not perform any respiratory function tests. Patient sub-group analyses were not performed. Even though there are studies that mention the positive effect of endobronchial treatment used together with surgery and chemoradiotherapy on survival, ${ }^{18,41}$ we did not analyse these effects. However, patients' clinical conditions improved in no complications were observed after endobronchial treatment, and they could adjust to adjuvant treatments more easily. It is difficult to find a large sample of patients without former treatment to test if endobronchial treatment alone can be successful in patients with lung cancer.

In conclusion, APC and EC are effective, rapid and repeatable methods for treating endoluminal airway lesions and effectively decrease dyspnoea. These techniques provide the safe restoration of airway patency in patients with a bronchial malignant or benign disorder.

\section{REFERENCES}

1. Santos RS, Raftopoulos Y, Keenan RJ, et al. Bronchoscopic palliation of primary lung cancer: single or multimodality therapy? Surg Endosc 18: 931-936, 2004.

2. Seaman JC, Musani Al. Endobronchial ablative therapies. Clin Chest Med 34: 417-425, 2013.

3. Minna J D, Higgins GA, Glaistein EJ. Cancer of the lung. In: De Vita VT, Hellman S, Rosemberg S A editors.cancer Principles and Practice of Oncology. Philedelphia, JB Lippincott, 1989: 591-705.

4. Chetty KG, Moran EM, Sassoon CS, et al. Effect of radiation therapy on bronchial obstruction due to bronchogenic carcinoma. Chest 95: 582-584, 1989.

5. Bolliger CT, Sutedja TG, Strausz J, Freitag L. Therapeutic bronchoscopy with immediate effect: laser, electrocautery, argon plasma coagulation and stents. Eur Respir J 27: 12581271, 2006.

6. Matsubara M, Yasuo M, Tanabe T, et al. Pleomorphic adenoma with an endobronchial resection. Intern Med 47: 1117 1120, 2008.

7. Altin S, Dalar L, Karasulu L, et al. Resection of giant endobronchial hamartoma by electrocautery and cryotherapy via flexible bronchoscopy. Tuberk Toraks 55: 390-394, 2007. 
8. Gao H, Ding X, Wei D, et al. Endoscopic management of benign tracheobronchial tumors. J Thorac Dis 3: 255-261, 2011.

9. Bugalho A, Oliveira A, Semedo J, et al. Argon-plasma treatment in benign metastasizing leiomyoma of the lung: a case reporta. Rev Port Pneumol 16: 921-923, 2010.

10. Paganin F, Prevot M, Noel JB, et al. A solitary bronchial papilloma with unusual endoscopic presentation: case study and literature review. BMC Pulm Med 18: 40, 2009.

11. Celik G, Ciledag A, Basa Akdogan B, et al. Bronchoscopic electrocautery therapy of a solitary endobronchial extramedullary plasmacytoma.Tuberk Toraks 58: 435-438, 2010.

12. Mikako M, Masanori $Y$, Tsuyoshi T, et al. Pleomorphic Adenoma with an Endobronchial Resection. Inter Med 47: 11171120, 2008.

13. Jin F, Mu D, Xie Y, et al. Application of bronchoscopic argon plasma coagulation in the treatment of tumorous endobronchial tuberculosis: Historical controlled trial. Thorac Cardiovasc Surg 145: 1650-1653, 2013.

14. Zaric B, Canak V, Milovancev A, et al. Endoscopic argon plasma coagulation for the management of solid, centrally located lung cancer. Arch Oncol 15: 94-96, 2007.

15. Ascedio J R, David C, Sérvulo A D, et al. Minimally invasive bronchoscopic resection of benign tumors of the bronchi. J Bras Pneumol 37: 796-800, 2011.

16. Masanori Y, Tanabe T, Tsushima K, et al. Endobronchial argon plasma coagulation for the management of post-intubation tracheal stenosis. Respirology 11: 659-662, 2006.

17. Morice RC, Ece T, Ece F, Keus L. Endobronchial argon plasma coagulation for treatment of hemoptysis and neoplastic airway obstruction. Chest 119: 781-787, 2001.

18. Sutedja TG, van Boxem TJ, Schramel FM, et al. Endobronchial electrocautery is an excellent alternative for Nd: YAG Laser to treat airway tumors. J Bronchology Interv Pulmonol 4:101105, 1997.

19. Wahidi MM, Unroe MA, Adlakha N, et al. The use of electrocautery as the primary ablation modality for malignant and benign airway obstruction. J Thorac Oncol 6: 1516-1520, 2011.

20. Bezzi M. Reopening the airway. Fast methods-Laser-AsistedMechanical Resection, Electrocautery, and Argon Plasma Coagulation. In: Jose Pablo Diaz-Jimenz, Alicia N Rodriguez. Intervention In Pulmonary Medicine. Springer Science+Business Media, Newyork, 2013: 99-120.

21. Coulter TD, Mehta AC. The heat is on: impact of endobronchial electrosurgery on the need for $\mathrm{Nd}$-yag laser photoresection. Chest 118: 516-521, 2000.

22. Sutedja G, Kralingen KV, Schramel FM, Postmus PE. Fibreoptic bronchoscopic electrosurgery under local anaesthesia for rapid palliation in patients with central airway mialignancies: a preliminary report. Thorax 49: 1243-1246, 1994.
23. Saenghirunvattana S, Buakham C, Masakul N, Saenghirunvattana R. Management of endobronchial cancer using bronchoscopic electrocautery. J Med Assoc Thai 89: 459-461, 2006.

24- Van Boxem T, Muller M, Venmans B, et al. Nd-YAG laser vs bronchoscopic electrocautery for palliation of symptomatic airway obstruction: a costeffectiveness study. Chest 116: 11081112, 1999.

25. Sato M, Terada $Y$, Nakagawa $T$, et al. Successful use of argon plasma coagulation and tranilast to treatgranulation tissue obstructing the airway after tracheal anastomosis. Chest 118: 1829-1831, 2000.

26. Miller SM, Bellinger CR, Chatterjee A. Argon plasma coagulation and electrosurgery for benign endobronchial tumors. $J$ Bronchology Interv Pulmonol 20: 38-40, 2013.

27. Crosta C, Spaggiari L, De Stefano A, et al. Endoscopic argon plasma coagulation for palliative treatment of malignant airway obstruction: early results in 47 cases. Lung Cancer 33: 75-80, 2001.

28. Keller CA, Hinerman H, Singh A, et al. The use of endoscopic argon plasma coagulation in airway complications after solid organ transplantation. Chest 119: 1968-1975, 2001.

29. Capaccio P, Peri A, Fociani P, et al. Flexible argon plasma coagulation treatment of obstructive tracheal metastatic melanoma. Am J Otolaryngol 23: 253-255, 2002.

30. Reichle G, Freitag L, Kullmann HJ, et al. Argon plasma coagulation in bronchology: a new method: alternative or complementary? Pneumologie 54: 508-516, 2000.

31. Amjadi K, Voduc N, Cruysberghs $\mathrm{Y}$, et al. Impact of interventional bronchoscopy on quality of life in malignant airway obstruction. Respiration 76: 421-428, 2008.

32. Bertoletti L, Elleuch R, Kaczmarek D, et al. Bronchoscopic cryotherapy treatment of isolated endoluminal typical carcinoid tumor. Chest 130: 1405-1411, 2006.

33. Vergnon JM, Huber RM, Moghissi K. Place of cryotherapy, brachytherapy and photodynamic therapy in therapeutic bronchoscopy of lung cancers. Eur Respir J 28: 200-218, 2006.

34. Sindhwani G, Rawat J, Keserwani V. Role of endobronchial electrocautery in management of neoplastic central airway obstruction: initial experience with seven cases. Indian J Chest Dis Allied Sci 54: 165-168, 2012.

35. Tremblay A, Marquette $\mathrm{CH}$. Endobronchial electrocautery and argon plasma coagulation: a practical approach. Can Respir $J$ 11: 305-310, 2004

36. Du Rand IA, Barber PV, Goldring J, et al. BTS Interventional Bronchoscopy Guideline group thorax. Summary of the British Thoracic Society guidelines for advanced diagnostic and therapeutic flexible bronchoscopy in adults. Thorax 66: 1014 1015, 2011.

37. Lee P, Kupeli E, Mehta AC. Therapeutic bronchoscopy in lung cancer. Laser therapy, electrocautery, brachytherapy, stents, and photodynamic therapy. Clin Chest Med 23: 241-56, 2002. 
38. Shaw Y, Yoneda KY, Chan AL. Cerebral Gas Embolism from Bronchoscopic Argon Plasma Coagulation: A Case Report. Respiration 83: 267-270, 2012.

39. Reddy C, Majid A, Michaud G, et al. Gas embolism following bronchoscopic argon plasma coagulation: a case series. Chest 134: 1066-1069, 2008.

40. Simpson GT, Strong MS, Healy GB, et al. Predictive factors of success or failure in the endoscopic management of laryngeal and tracheal stenosis. Ann Otol Rhinol Laryngol 91: 384-388, 1982.

41. Han CC, Prasetyo D, Wright GM. Endobronchial palliation using Nd:YAG laser is associated with improved survival when combined with multimodal adjuvant treatments. J Thorac Oncol 2: 59-64, 2007.

\section{Correspondence}

Dr. Aydan MERTOĞLU

Gaziler Caddesi, No: 331

35110 Yenişehir

IZMIR / TURKEY

Cell: (+90-532) 3607160

Fax: (+90-232) 4587262

e-mail: aydancakan@yahoo.com 